\title{
RAIN INTERCEPTION IN A SECONDARY FRAGMENT OF ARAUCARIA FOREST WITH FAXINAL, GUARAPUAVA-PR
}

Keyworks:

soil degradation pasture

forest hydrology sustainability

Histórico:

Recebido 05/07/2013

Aceito 12/03/2015

Palavras chave:

manejo do solo

precipitação interna

hidrologia florestal

sustentabilidade

Correspondence: thomaz@unicentro.br
ABSTRACT: Forest management can alter the structure of vegetation (layer), particularly in areas used for pasture, such as the Faxinal areas in the south central region of Paraná, Brazil. Therefore, the aims of the present study were as follows: a) to assess rain interception in secondary forests; b) to estimate the maximum precipitation intercepted by the forest; and c) to discuss the possible implications of throughfall for the hydrologic processes of the secondary forest (Faxinal). Nine 20-cm-diameter rain gauges $\left(3 / 4 \mathrm{~cm}^{2}\right)$ were used. Rain gauges were distributed randomly throughout the forest and were successively rotated after a specific number of rainfalls. A total of 66 rainfall events of different volumes were recorded. We observed that an increase in rain volume tended to homogenize the rainfall interception rate in the forest. Consecutive rainfalls did not significantly influence the interception rate in the secondary forest. However, the interception in the secondary forest $(10.5 \%)$ was lower than the mean interception rate recorded in other Brazilian forests.

\section{INTERCEPTAÇÃO DE CHUVA EM FRAGMENTO SECUNDÁRIO DE OMBRÓFILA MISTA COM FAXINAL, GUARAPUAVA - PR}

RESUMO: O manejo em florestas pode causar a desestruturação da vegetação (estratos), especialmente, em regiões utilizadas para pastagem, como é o caso de áreas com Faxinais na região Centro Sul do Estado do Paraná. Assim, os objetivos deste estudo foram: a) a análise da interceptação da chuva em área ocupada por floresta secundária; b) a estimativa da precipitação máxima interceptada pela respectiva floresta; e, c) discutir as possíveis implicações da precipitação interna nos processos hidrológicos de floresta secundária (Faxinal). Para isso, utilizou-se nove pluviômetros com $20 \mathrm{~cm}$ de diâmetro $\left(3 / 4 \mathrm{~cm}^{2}\right)$. Os pluviômetros foram distribuídos ao acaso no interior da floresta, os quais foram submetidos à constante variação de suas posições após os eventos de chuvas. Foram registrados 66 eventos pluviométricos com diferentes volumes. Verificou-se que 0 aumento do volume de chuva tende a homogeneizar a taxa de interceptação da floresta. As chuvas consecutivas não apresentaram influência significativa na taxa de interceptação da floresta secundária. Contudo a interceptação da floresta secundária (10,5\%) está abaixo da média de interceptação registrada em outras florestas brasileiras. 


\section{INTRODUCTION}

Water circulates in a drainage basin by passing through various subsystems (e.g., vegetation, soil surface, and soil) before reaching the river channel. Water that falls on the soil surface is first distributed in the vegetation subsystem. The canopy acts as a regulator by directing the flow and storing water from precipitation. Thus, if the canopy retains precipitation, water is not transferred to the plant litter via throughfall and stemflow. This water is lost to the atmosphere through evaporation (ANDERSON and BURT, 1990).

Many studies have been conducted on the interaction of a variety of processes in forest ecosystems, such as interception (ARCOVA et al., 2003), stemflow (GERMER et al., 20I0), plant litter interception (WALLACE and OLIVER, 1990; ATARROFF and RADA, 2000), plant litter input and nutrient production (FERNANDES et al., 2006), and forest nutrient input from precipitation (SCHEER, 2009), among other studies.

Agroforestry systems have also been studied with regard to management, soil conservation, and other environmental processes, such as the impact of the eucalyptus agroforestry system (LIMA, 1996), rain interception in pinus plantations (LIMA and NICOLIELO, 1983), nutrient dynamics in planted commercial forests (MACKENSEN et al., 2003), soil loss in agroforestry systems (MARTINS et al., 2003), and interception and stemflow in agroforestry systems in Amazonia (SCHROTH et al., 1999).

The economic, social, cultural, and environmental features of a particular case of a forest-grazing system in the south central region of Paraná, called Faxinal, have been studied (CHANG, 1988). However, there are only a few studies on the environmental processes in this system (THOMAZ, 2007).

The Faxinal system is a type of farming system that is characterized by a) extensive animal production in communal grazing land within the Araucaria Forest; b) agricultural production that consists of subsistence crops for the domestic supply of food and commercialization of the surplus; and c) yerba mate collection in native mate plantations within the communal grazing land and between crop harvests, representing an additional income (CHANG, 1988).
In the Faxinal areas, the amount of deposited plant litter is affected by pasture because animals feed on some species of leaves and fruits. In addition, animals such as pigs turn the soil and expose the $\mathrm{O}_{2}$ horizon (decomposing plant litter). This exposure affects erosion processes. Since understory and herbaceous vegetation are not usually present in Faxinal areas, this exposed soil suffers the direct impact of rain droplets (splash effect) via dripping from the canopy, which contributes to the disaggregation of soil aggregates and thereby increases soil loss (ANTONELI, 20I I).

The study of hydrological processes in the Araucaria secondary forest (Faxinal) is virtually nonexistent in the literature. Thus, the hypothesis of this study is as follows: areas of the secondary forest that are used for pasture, in the south central region of Paraná, which the canopy is dominated by araucaria (Araucaria angustifolia), have a lower interception capacity due to forest thinning. In addition, the purpose of this study is to discuss the possible implications of throughfall for the hydrological processes of the secondary forest (Faxinal).

\section{METHODS AND MATERIALS}

\section{Characteristics of the study area and of the monitored forest}

The area under study is located in the municipality of Guarapuava in the state of Paraná (coordinates at the center of the forest fragment: $25^{\circ} 24^{\prime} \mathrm{S}$ and $51^{\circ} 24^{\prime} \mathrm{O}$ ). The climate of Guarapuava is under the influence of the extratropical area, which results in mesothermal temperatures. The mean annual temperature is $17.1 \pm$ $0.47^{\circ} \mathrm{C}$ and the mean annual evaporation rate is 835.1 $\pm 123.9 \mathrm{~mm}$. Rainfall is abundant and occurs throughout the year (annual mean: $1953.8 \pm 389.7 \mathrm{~mm}$ ) (THOMAZ and VESTENA, 2003).

The secondary forest has an area of 3.7 ha that covers the convex relief with a slope length of approximately $350 \mathrm{~m}$ and a mean slope of $12.5 \%$ (Altitude: I,060 m). The relief of the area under study varies from rolling (8-20\% slope) to strongly rolling (20-45\% slope). The soil is derived from basaltic rock and is composed of an association of humic Cambisol and litholic humic Neosol (silt 13.5\%, sand $22.0 \%$, and clay $64.5 \%)$. The soil depth varies from shallow $(<50 \mathrm{~cm})$ to moderately deep (< I.0 m) (Embrapa, 2006). 
The secondary forest (Faxinal) has a 20-m-high canopy that is dominated by Araucaria angustifolia (Bert. O. Ktze). The sparse lower stratum is between 6 and $12 \mathrm{~m}$ high and is composed of a variety of species such as Nectranda lanceolata (Nees \& Mart. ex Nees), Nectranda megapotamica ([Spreng.] Mez), Campomanesia xanthocarpa (O. Berg), Ilex paraguariensis (A. St.-Hil.), Ocotea pulchella (Nees Mez), and Capsicodendron dinisii (Schwacke). The herbaceous stratum is virtually absent due to animal grazing and thinning performed by the landowner. The secondary forest has a density of 3.075 \pm 607.6 trees per hectare with $\mathrm{dbh} \geq 10 \mathrm{~cm}$.

\section{Interception monitoring}

Rain interception monitoring in the secondary forest recorded 66 rainfall events of different volumes. Nine 20 -cm-diameter rain gauges $\left(3 / 4 \mathrm{~cm}^{2}\right)$ were used for measurements, and the edge of the rain gauge was approximately $0.5 \mathrm{~m}$ above the ground. The nine rain gauges were randomly distributed throughout the monitored area, and a rotation system was applied, in which the collectors were moved to a different point of collection after every five rainfall events (HELVEY and PATRIC, 1965; DUNNE and LEOPOLD, 1978). The purpose of this procedure was to assess the diversity within the secondary forest (e.g., canopy dominated by araucaria, canopy + understory, internal clearings, etc.). Total precipitation (clearing) was measured using two rain gauges (Hellmann) deployed $200 \mathrm{~m}$ from the edge of the forest. Loss by interception in the canopy was measured using the equation I $=\mathrm{TP}-\mathrm{T}$, in which
$\mathrm{I}=$ interception $(\mathrm{mm}), \mathrm{TP}=$ total precipitation in the clearing $(\mathrm{mm})$, and $\mathrm{T}=$ throughfall $(\mathrm{mm})$.

\section{Data analysis}

Data were tabulated and statistical analysis was performed as follows: I) descriptive statistics (mean, standard deviation, and coefficient of variation) and 2) Pearson simple linear correlation analysis. The parameters in each statistical analysis were evaluated with a p-value of $0.05 \%$ in order to detect the effect of the hydrological parameters. Rain interception capacity was obtained using the linear model $y=a x+b$ (Figure 2). The statistical analysis was performed through the BioEstat 5.3 software (AYRES et al., 2007).

\section{RESULTS AND DISCUSSION}

During the monitoring period, 66 rainfall events were recorded (total rain: I, $190.4 \mathrm{~mm}$ ). Of this total volume, I,065.I mm resulted in throughfall (89.5\%) and $125.3 \mathrm{~mm}$ was intercepted by the forest (10.5\%). Moreover, throughfall and interception varied according to rain volume (Table I). The greatest interception occurred in rainfalls of less than $2.5 \mathrm{~mm}$ (56.3\%). Interception capacity decreased gradually in the remaining classes of rainfall until it reached a minimum value of $3.7 \%$ in rainfalls of more than $50 \mathrm{~mm}$ (Figure IA).

During the measuring period, a mean interval of 3.2 days between rainfalls was observed, as well as the occurrence of consecutive days with rain ( $2-5$ days). However, this did not affect the interception capacity of the forest $(r=0.046 ; p<0.05 \%)$. In the beginning of the

TABLE 1 Hydrological parameters measured in the secondary forest according to rainfall class.

TABELA 1 - Parâmetros hidrológicos mensurados em floresta secundária de acordo com a classe de chuva.

\begin{tabular}{cccccccc}
\hline $\begin{array}{c}\text { Class of rainfall } \\
(\mathrm{mm})\end{array}$ & Frequency Mean precipitation & \multicolumn{2}{c}{ Throughfall } & \multicolumn{2}{c}{ Interception } & $\begin{array}{c}\text { Coefficient of variation of } \\
\text { interception }\end{array}$ \\
& & $(\mathrm{mm})$ & $(\mathrm{mm})$ & $(\%)$ & $(\mathrm{mm})$ & $(\%)$ & $(\%)$ \\
\hline$<2.5$ & 9 & 1.6 & 0.7 & 43.7 & 0.9 & 56.3 & 51.7 \\
$2.5-5$ & 8 & 4.1 & 2.8 & 68.3 & 1.3 & 31.7 & 32.5 \\
$5-10$ & 14 & 6.9 & 5.4 & 78.3 & 1.4 & 21.7 & 38.1 \\
$10-20$ & 13 & 14.1 & 12.3 & 87.2 & 1.8 & 12.8 & 22.7 \\
$20-30$ & 10 & 25.4 & 22.9 & 90.2 & 2.5 & 9.8 & 17.7 \\
$30-40$ & 3 & 33.7 & 32.0 & 95.0 & 1.9 & 5.0 & 16.7 \\
$40-50$ & 6 & 44.3 & 40.3 & 91.0 & 4.0 & 9.0 & 16.7 \\
$>50$ & 3 & 80.7 & 77.7 & 96.3 & 3.0 & 3.7 & 12.3 \\
\hline Total & 66 & - & - & - & - & - & - \\
\hline
\end{tabular}



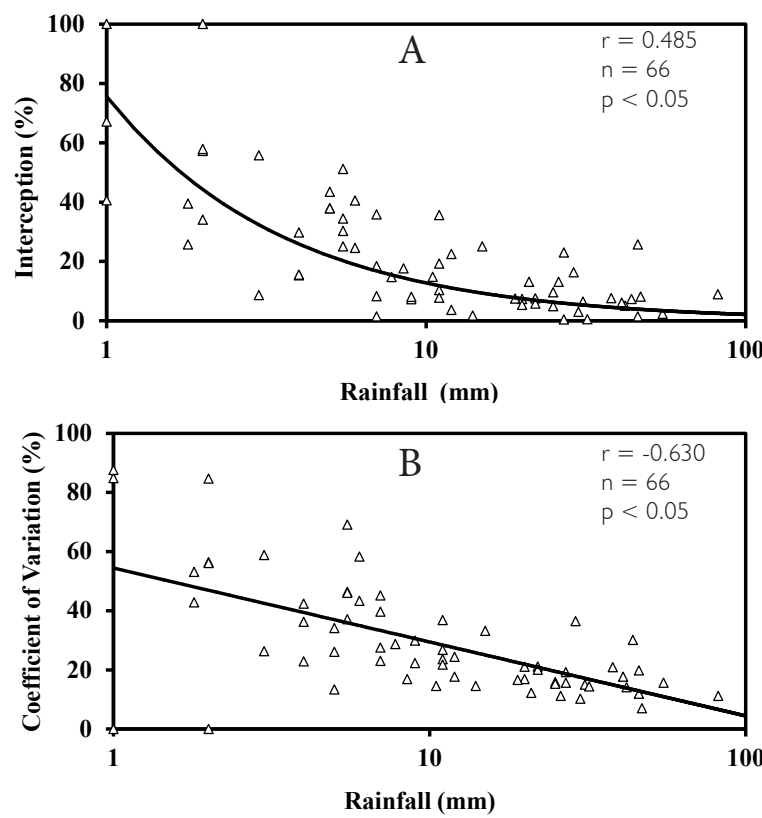

FIGURE 1 A) Interception as a function of rain volume; B) coefficient of variation (CV) as a function of rain volume.

FIGURA 1 A) Relação da interceptação em função do volume de chuva; B) Relação do Coeficiente de Variação (CV) em função do volume da chuva.

rain event, the interception capacity of the canopy is high, but the canopy becomes saturated as larger volumes of precipitation accumulate; throughfall occurs, and water is transferred to the lower strata until it reaches the plant litter. Crockford and Richardson (2000) stated that interception is more affected by intense rainfall of short duration than by long-lasting rainfall. Germer et al. (2010), on the other hand, observed that the increase of stemflow in the Amazonian rainforest was more affected by the amount of rain (volume) than by its intensity. The present study showed that interception was not affected even when the canopy was saturated (saturation being common after consecutive rainfalls associated with frontal weather systems).

Interception variability increased markedly with decreasing rain volume. In rainfalls of less than $20 \mathrm{~mm}$, the mean coefficient of variation (MCV \%) was $35.3 \%$. In rainfalls of more than $20 \mathrm{~mm}$, the variation was $17.1 \%$ (Table I). There was a significant correlation between the increase in precipitation and the decrease in the coefficient of variation $(r=-0.630 ; p<0.05 \%)$ (Figure IB).

Two explanations can account for this behavior. The first is the homogenization of throughfall in the forest due to the dominance of araucaria (canopy), which has a low interception capacity, as well as the scarcity (thinning) of the understory and the absence of the herbaceous stratum. The second is the characteristic of the environmental variable itself, since the higher the measured rate, mass, or volume, the smaller the variation of the variable (see NEARING et al., 1999). According to the regression equation (Figure 2), the secondary forest can completely intercept a rainfall of up to 1.3 $\mathrm{mm}(\mathrm{p}<0.05 \%)$. This value is similar to that estimated by Lima and Leopoldo (1999) (I.4 mm) for the riparian forest (Cerradão) and for the Araucaria Forest (1.2 mm) (CALUX and THOMAZ, 20I2).

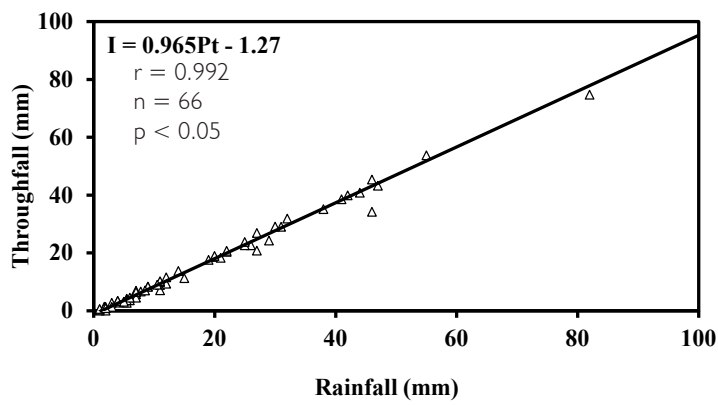

FIGURE 2 Throughfall as a function of rain volume (total precipitation) Note: $I=$ interception and $\mathrm{Pt}=$ total precipitation.

FIGURA 2 Precipitação interna em função do volume da chuva (Precipitação total). Observação: I = interceptação e $\mathrm{Pt}=$ precipitação total.

The variation in the forest's hydrological processes is associated with factors such as the physical characteristics of the rain (intensity, volume, duration, frequency, and seasonality), the morphological characteristics of the trees, the type of forest, the type of canopy, the type of trunk, the composition/distribution of the understory, and the presence of a herbaceous layer (LUNDGREN and LUNDGREN, 1979; VIS, 1986; LIU, 200I; GEMER et al., 20I0).

Therefore, comparing data obtained in different ecosystems is difficult (Table 2). Interception in rainforest ecosystems varies between 15 and 35\% (LUNDGREN and LUNDGREN, 1979). Liu (200I) analyzed a variety of forest ecosystems and reported interception between 10 and $30 \%$. With regard to Brazil, the interception rate reported in the literature varies from 5 to $37.6 \%$ (mean $=21.1 \pm 8.0 \%$ and $\mathrm{n}=17$ ).

The interception rate recorded in the present study was close to the lower limit reported in the international literature (10-15\%) (DUNNE and 
TABLE 2 Interception rates in different forest phytophysionomies and countries.

TABELA 2 Taxa de interceptação em áreas florestadas de diferentes fitofisionomias e países.

\begin{tabular}{|c|c|c|c|c|}
\hline Author & Forest & Country & $\begin{array}{c}\text { Rainfall } \\
(\mathrm{mm})\end{array}$ & $\begin{array}{c}\text { Interception } \\
(\%)\end{array}$ \\
\hline Lundgren and Lundgren (I979) & Tropical Rainforest & Tanzania & $\mathrm{I}, 227$ & 22 \\
\hline Vis (1986) & Altitude Tropical Rainforest & Colombia & $1,600-2,800$ & II- 20 \\
\hline Lima and Leopoldo (1999) & $\begin{array}{l}\text { Riparian Forest } \\
\text { (cerradão) }\end{array}$ & Brazil & $\mathrm{I}, 537$ & 37.6 \\
\hline Schroth et al. (1999) & $\begin{array}{c}\text { Equatorial Forest } \\
\text { (agroforestry system) }\end{array}$ & Brazil & 2,622 & $0.5-13.9$ \\
\hline Arcova et al. (2003) & Atlantic Forest & Brazil & 2,240 & 18.6 \\
\hline Oliveira Júnior and Dias (2005) & $\begin{array}{c}\text { Tropical Rainforest } \\
\text { (Secondary Atlantic Forest) }\end{array}$ & Brazil & $\mathrm{I}, 345$ & 18.3 \\
\hline Oyarzun et al. (20II) & Temperate Rainforest & Chile & 4,370 & II - 36 \\
\hline Scheer $(20 \mathrm{II})$ & $\begin{array}{c}\text { Tropical Rainforest } \\
\text { (Secondary Atlantic Forest) }\end{array}$ & Brazil & 2,235 & 17.3 \\
\hline Calux and Thomaz (20I2) & Araucaria Forest & Brazil & 1,600 & 14.5 \\
\hline
\end{tabular}

LEOPOLD, 1978; LUNDGREN and LUNDGREN, 1979; LIU, 200I; OYARZUN et al., 20II). The interception rate in the secondary forest (Faxinal) was lower than the interception rates recorded in most Brazilian forests (Table 2). However, the interception rate was similar to that recorded in the Araucaria Forest (CALUX and THOMAZ, 20I2).

The interception measured in the canopy was as expected, because the morphological characteristic of the araucaria tree top (horizontal branches) does not favor the occurrence of significant stemflow; this process is more common in trees with inclined and converging branches (CROCKFORD and RICHARDSON, 2000). Huber and Iroumé (200I) noted an increase in the interception rate and a reduction in the stemflow rate with tree development and growth in a conifer forest. These authors concluded that this happened because conifer branches tended to become horizontal, which increased interception capacity at the expense of stemflow.

A low interception capacity can have an effect on the hydrological processes of the secondary forest (Faxinal) especially through the internal characteristics of the forest, due to the changing structure of the intermediary and lower strata (thinning) and the subsequent reduction in plant litter input. In the secondary forest (area under study), the stored plant litter was estimated to be $12.5 \mathrm{t} \cdot \mathrm{ha}^{-1}$, whereas in the araucaria forest, it reached $22.6 \mathrm{t} \cdot \mathrm{ha}^{-1}$ (THOMAZ, 2007). In addition, the author noted that the high variability $(47 \%)$ of stored plant litter in the secondary forest was associated with the previously mentioned factors (irregular canopy and thinning of lower strata), which results in the discontinuous distribution of plant litter on the forest floor.

Plant litter is important for the interception of throughfall and for water retention. A review conducted by Dunne and Leopold (1978) indicated that the interception of rainfall by plant litter can vary between 2 and $4 \%$ in a conifer forest ecosystem. Wallace and Oliver (1990) reported an interception capacity of plant litter of between 10 and $15 \%$. In a study performed in the mountain tropical forest in Venezuela, the interception reached 6\% (ATARROFF and RADA, 2000).

At this time, the secondary forest (Faxinal) in the south central region of Paraná is a forest-grazing system with a low to nonexistent technological component (THOMAZ, 20I I). Many alterations are observed in this system, such as forest thinning (lower strata), reduction of plant litter input into the forest floor, changes in rain interception, soil compaction caused by cattle trampling, ravine formation in the cattle's path, mass failure on stream margins, and increased sediment yield in streams (THOMAZ and DIAS, 2009). 


\section{CONCLUSION}

The aim of the present study was to assess the rain interception in the secondary forest and to analyze possible implications of interception for the hydrological processes of the secondary forest (Faxinal). The main conclusions are as follows: a) interception in the secondary forest $(10.5 \%)$ was lower than the mean interception recorded in other Brazilian forests; b) consecutive rainfalls did not significantly affect the interception rate in the secondary forest. Moreover, the increase in rain volume tended to homogenize the interception rate in the forest and consequently reduce the variability of throughfall (coefficient of variation); c) the use of the secondary forest as pasture generally leads to alterations in the structure of lower strata (shrub, understory, and herbaceous stratum) as a result of thinning (to allow sunlight to penetrate the forest) and cattle trampling. These practices result in the reduction of rain interception. d) thinning can reduce the input of plant litter, which affects rain interception.

\section{ACKNOWLEDGEMENTS}

I would like to thank the farmer, Joel Araujo Silvério, for allowing us to conduct research and data collection on his property.

\section{REFERENCES}

ANTONELI, V. Dinâmica do uso da terra e a produção de sedimentos em diferentes áreas fontes na bacia hidrográfica do Arroio Boa Vista- Guamiranga-PR. Tese Doutorado. Universidade Federal do Paraná - UFPR. Curitiba 20I I. $354 \mathrm{p}$

ANDERSON, M. G.; BURT, T. P. Process studies in hillslope hydrology: an overview. In. ANDERSON, M. G. \& BURT, T. P. (eds.). Process studies in hillslope hydrology. Baffins Lane, Chichester, John Wiley \& Sons. p. I - 8, 1990.

ARCOVA, F. C. S. et al. Precipitação efetiva e interceptação das chuvas por floresta de mata atlântica em uma microbacia experimental em Cunha - São Paulo. Revista Árvore, v.27, n.2, p.257-262, 2003

ATAROFF, M.; RADA, F. Deforestation impact on water dynamics in a Venezuelan Andean Cloud Forest. Ambio, v. 29, n. 7, p. 440-444, 2000.

AYRES, M.; M. AYRES JR.; D.L. AYRES \& A.S. SANTOS. 2003. BioEstat 5.3. Aplicações estatísticas nas áreas das ciências biológicas e médicas. Belém, Sociedade Civil Mamirauá, 290p.
CALUX, J.; THOMAZ, E. L. Interceptação e precipitação interna: comparação entre floresta ombrófila mista e Pinus elliotttii var. elliotti. Geoambiente On-line, v. 19, p. 24-39, 2012.

CHANG, M. Y. Sistema Faxinal: uma forma de Organização Camponesa em Desagregação no Centro-Sul do Paraná. Londrina: IAPAR, Boletim Técnico, n. 22, 1988.

CROCKFORD, R. H. e RICHARDSON, D. P. Partitioning of rainfall into throughfall, stemflow and interception: effect of forest type, ground cover and climate. Hydrological Processes, n. I4, p. 2903-2920, 2000.

DUNNE, T.; LEOPOLD, L. B. Water in environmental planning. New York: W. H. Freeman and Company, 1978. 8I8p.

EMPRAPA. Centro Nacional de Pesquisa de Solos. Sistema Brasileiro de Classificação de Solos. Rio de Janeiro. 2 ed. Rio de Janeiro: Embrapa Solos, 2006, 306p.

FERNANDES, M. M. et al. Aporte e decomposição de serapilheira em áreas de floresta secundária, plantio de sabiá (Mimosa caesalpiniaefolia Benth.) e andiroba (Carapa guianensis Aubl.) na flona Mário Xavier, RJ. Ciência Florestal, v. 16, n. 2, p. 163-175.

GERMER, S. et al. Have we underestimated stemflow? Lessons from an open tropical rainforest. Journal of Hydrology, $n$. 395, p. 169-179, 2010.

HELVEY, J. D.; PATRIC, J. H. Design criteria for interception studies. International Association of Scientific Hydrology, Symposium Design of Hydrological Networks, Publication n. 87, p. $|3|-\mid 37,1965$.

HUBER, A. M.; OYARZÚN, C. E. Redistribución de las precipitaciones en un bosque siempreverde del sur de Chile. Turrialba, v. 42, n. 2, p. 192-199. 1992.

HUBER, A.; IROUMÉ, A. Variability of annual rainfall partitioning for different sites and Forest covers in Chile. Journal of Hydrology, n. 248, p. 78-92, 2001.

LIMA, P. R. A.; LEOPOLDO, P. R. 1999. Interceptação de chuva por mata ciliar na região central do estado de São Paulo. Energia na Agricultura, v. 14, n.3, p. 25-33, 1999.

LIMA, W. P.; NICOLIELO, N. Precipitação efetiva e interceptação em florestas de pinheiros tropicais e em reserva de cerradão. IPEF, n. 24, p.43-46, 1983.

LIMA, W. P. Impacto ambiental do eucalipto. São Paulo: EDUSP, 1996. $30 \mathrm{Ip}$

LIU, S. Evaluation of the Liu model for predicting rainfal interception in forest wolrd-wide, Hydrological Processes, v. I5, p. 234I-2360, 200I.

LUDGREN, L.; LUDGREN, B. Rainfall, interception and evaporation in the Mazunbai Forest Reserve, West Usambara Mts., Tanzania and their importance in the assessment of land potential. Geografiska Annaler: Series A, Physical Geography, n. 6I, p.157-178, 1979. 
MACKENSEN, J. et al. Assessment of management-dependent nutrient losses in tropical industrial tree plantations. Ambio, v. 32, n. 2, p. I06-II2, 2003.

MARTINS, S. G. et al. Perdas de solo e água por erosão hídrica em sistemas florestais na região de Aracruz (ES). R. Bras. Ci. Solo, n. 27, p. 395-403, 2003.

NEARING, M. A. et al. Variability in soil erosion data from replicated plots. Soil Sci. Soc. Am. J. n. 63, p. 1829-1835, 1999.

OLIVEIRA JÚNIOR, J. C., DIAS, H. C. T. Precipitação efetiva em fragmento secundário da mata atlântica. Revista Árvore, v.29, n.I, p.9-15, 2005.

OYARZUN, C.E. et al. Seasonal and annual throughfall and stemflow in Andean temperate rainforests. Hydrological Processes, v. 25 n. 4, p. 623-633, 201 I.

SCHEER, M. B. Fluxo de nutrientes pela precipitação pluviométrica em dois trechos de floresta ombrófila densa em Guaraqueçaba, Paraná. Floresta, v. 39, n. I, p. II7I30, 2009.

SCHEER, M. B. Mineral nutrient fluxes in rainfall and throughfall in a lowland Atlantic rainforest in southern Brazil. Journal of Forest Research, v. 16, 76-8I, 2011.

SCHROTH, G. et al. Distribution of throughfall and stemflow in multi-strata agroforestry, perennial monoculture, fallow and primary forest in central Amazonia, Brazil. Hydrological Processes, v. 13, n. 10, p. 1423-1436, 1999.

SILVA, A.M. et al. Erosão e hidrossedimentologia em bacias hidrográficas. São Carlos. RiMa. 2003, 140 p.

THOMAZ, E. L. Sistema Faxinal: pesquisa na UNICENTRO e as perspectivas de estudos ambientais. Terr@ Plural (UEPG. Impresso), v. 5, p. 199-212, 201 I.
THOMAZ, E. L. Dinâmica do uso da terra e degradação do solo na bacia do Rio Guabiroba - Guarapuava/PR. RA'E GA, n. I3, p. I09-I28, 2007.

THOMAZ, E. L. Processos hidrogeomorfológicos e o uso da terra em ambiente subtropical - Guarapuava - PR. São Paulo, 297f. Tese de Doutorado em Ciência, área Geografia Física, Faculdade de Filosofia Letras e Ciências Humanas, DEPARTAMENTO DE GEOGRAFIA, UNIVERSIDADE DE SÃO PAULO, 2005.

THOMAZ, E. L.; DIAS, W. A. Bioerosão - evolução do rebanho bovino brasileiro e implicações nos processos geomorfológicos. Revista Brasileira de Geomorfologia, v. I0, n. 2, p. 3-II, 2009.

THOMAZ, E. L.; VESTENA, L. R. Aspectos Climáticos de Guarapuava - PR. Guarapuava, Editora UNICENTRO, 2003, 106p.

THOMAZ, E. L.; VITOR, M. R. Caracterização de serrapilheira em Floresta Temperada com Araucária - Guarapuava - PR. In: I SEMINÁRIO DE PESQUISA EM GEOGRAFIA FÍSICA, I, São Paulo, dezembro 2003. Perspectivas da pesquisa em Geografia Física. Universidade de São Paulo, 2003. v. I, p 20I-207.

VIS, M. Interception, drop size distribution and rainfall kinetic energy in four Colombian forest ecosystems. Earth Surface Processes and Landforms, v. II, n. 6, p. 59I603, 1986.

WALLACE, J. S.; OLIVER, H. R. Vegetation and hydroclimate. In: ANDERSON, M. G.; BURT, T. P. (org.). Process studies in hillslope hydrology. Baffins Lane, Chichester, John Wiley \& Sons. 1990, p. 9-4I. 